\title{
Využití českého úřradu zeměměřického a katastrálního jako zdroje informací
}

\author{
Use of the Czech Office of Land and Cadastre as Information Sources
}

\author{
Milada Komosná*, Alena Gardášová, Lucie Škopková \\ Vysoké učeni technické v Brně, Ústav soudního inženýrství
}

\begin{abstract}
Abstrakt
Článek uvádí možnosti využití webových stránek Českého úřadu zeměměřického a katastrálního, které se v posledních letech stávají důležitým online zdrojem při vyhledávání podkladů nejen při zpracování znaleckých posudků. Tento článek byl publikován na XXVII. Mezinárodní vědecké konferenci soudního inženýrství ExFoS 2018, 1. - 2. 2. 2018.
\end{abstract}

Klíčová slova: nemovitost, katastr nemovitostí, údaje o cenách, věcná břemena, nesoulady.

\section{1. ÚVOD}

Český úřad zeměměřický a katastrální se stal v posledních letech důležitým zdrojem při vyhledávání podkladů k vypracování znaleckých posudků. Článek si klade za cíl přehledně informovat o dostupných možnostech, které nabízí a uvést poznatky a užitečnost při jejich využití.

Od 1. ledna 2014 nabyl účinnosti nový katastrální zákon č. 256/2013 Sb. [1] spolu s dlouho očekávaným občanským zákoníkem č. 89/2012 Sb. [2]. V občanském zákoníku § 498 je definován pojem nemovitá věc. Tento pojem se důsledně užívá v předpisech, katastrální zákon však zvolil užívání pojmu „,nemovitost“ jako legislativní zkratku [3].

Český úřad zeměměřický a katastrální nabízí uživatelům využívat služeb státní správy a nahlížet do katastru nemovitostí. Autorky článku se snaží čtenářům přiblížit, jaké informace jsou volně dostupné a dohledatelné na webových stránkách ČÚZK. Zaměřují se na informace, které jsou dostupné i přes mapový portál Marushka.

\begin{abstract}
The article presents the possibilities of using the website of the Czech Office of Land and Cadastre, that are an important online source for searching documents not only for preparation of expert opinions. The article was published at XXVII. International Scientific Conference on Forensic Engineering ExFoS 2018, 1-2 February 2018.
\end{abstract}

Keywords: real estate, land registry, pricing data, easements, inconsistencies.

\section{2. ČESKÝ ÚŘAD ZEMĚMĚŘICKÝ A KATASTRÁLNÍ}

Vznikem České republiky, tj. 1. ledna 1993, začal platit zákon o katastru nemovitostí České republiky č. 344/1992 Sb. (katastrální zákon) [4] a zákon o zápisech vlastnických a jiných věcných práv k nemovitostem č. 265/1992 Sb. [5]. Státní správa katastru začala evidovat právní vztahy k nemovitostem již pouze na území České republiky. Druhým zlomovým bodem, který přinesl změny v katastru, je 1. leden 2014, kdy vešel v platnost nový katastrální zákon č. 256/2013 Sb., zákon o katastru nemovitostí [1] spolu s dlouho očekávaným novým občanským zákoníkem č. 89/2012 Sb. [2]. V katastrálním zákonu hned v $§ 1$ je katastr definován jako „veřejný seznam“ - každý občan má právo nahlížet do katastru nemovitostí a získávat informace o nemovitostech.

Český úřad zeměměřický a katastrální (ČÚZK) nabízí veřejnosti využívat jeho služeb a stále doplňuje informace o nemovitostech evidovaných na území České republiky. V dnešní době jsou informace snadno dostupné i z webových stránek ČÚZK - www. cuzk.cz [6]. 


\subsection{Dostupné informace $\mathrm{z}$ katastru nemovitostí}

\subsubsection{Obecně}

- Nahlížení do katastru nemovitostí (http://nahlizenidokn. cuzk.cz/),

- vyhledat parcelu,

- vyhledat stavbu,

- vyhledat jednotku,

- vyhledat rízení,

- zobrazení mapy

- cenové údaje (http://nahlizenidokn.cuzk.cz/nas/ cenoveudaje/cr/),

- dálkový přístup do katastru nemovitostí (https://www.cuzk. cz/aplikace- $d p$ ).

Nahlížení do katastru nemovitostí je již veřejnosti všeobecně známo. Občan, který využívá těchto volně dostupných služeb, je obeznámen s možností stáhnout si ,informativní výpis“o o předmětné nemovitosti. Od ledna roku 2014 je na informativním výpise možno získat i informaci o ,„rízení, v rámci kterých byl zapsán cenový údaj“. Pokud řízení proběhlo již v roce 2014, je zde dohledatelné číslo vkladu. Cenový údaj však již volně dostupný není. Je možné jej získat bud” v rámci placené služby z „dálkového př́stupu“ nebo si zajít pro listinnou podobu. $\mathrm{V}$ př́padě elektronicky vedených vkladů jsou kupní smlouvy k získání na jakémkoliv pracovišti, nejen na pracovišti, kde byl vklad povolen. Poplatky za jednotlivé služby nabízené katastrem se ř́dí vyhláškou č. 358/2013 Sb., o poskytování údajů z katastru nemovitostí, v platném znění [7].

Webové stránky ČÚZK nabízí v aplikaci nahlížení do katastru i výřez katastrální mapy přes mapový portál Marushka. V tomto portálu je možno výřrez katastrální mapy přepnout do soutisku katastrální mapy a ortofoto snímku. Dále nabízí možnost získání informací přes funkci „vrstvy“, kde jsou uživatelům zpřístupněny další možnosti využití dle jejich potřeb.

Článek je zaměřen na 4 vybrané služby:

- věcná břemena,

- nemovitosti s cenovými údaji,

- nemovitosti řešené ÚZSVM,

- nemovitosti s nesoulady.

\subsubsection{Vĕcná břemena}

Z „informativního výpisu“ v aplikaci nahlížení do katastru v kolonce „omezení vlastnického práva“ je uvedena informace, zda je nemovitost zatížena věcným břemenem. Výhodou použití mapového portálu je, že si nově uživatel může zobrazit rozsah věcných břemen. Tato služba je velmi dobře využitelná právě $\mathrm{v}$ př́padech, kdy věcné břemeno nezatěžuje celou parcelu.

U zobrazení mapy je nutno rozkliknout ,vrstvy“, kde si uživatel vybere zobrazení věcných břemen. Je zde možnost dvojího zobrazení:

- „hranice věcných břemen“,

- ,plochy“.

V prvním př́ípadě tedy zaškrtnutím políčka „hranice věcných břemen“" se zobrazí omezení k části parcely, viz následující obrázky.

Obr. 1 je vložen $z$ ilustračních důvodů, kde věcné břemeno není zaneseno, na obr. 2 je již věcné břemeno zaneseno formou přerušované žluté (viz obálka) čáry.

Ve druhém prrípadě tedy zaškrtnutím políčka „plochy“ se zobrazí barevně plocha parcely, která je zatížena věcným břemenem.

Zde se však nabízejí další možnosti výběru:

- zatížení celé parcely,

- zatížení části parcely.

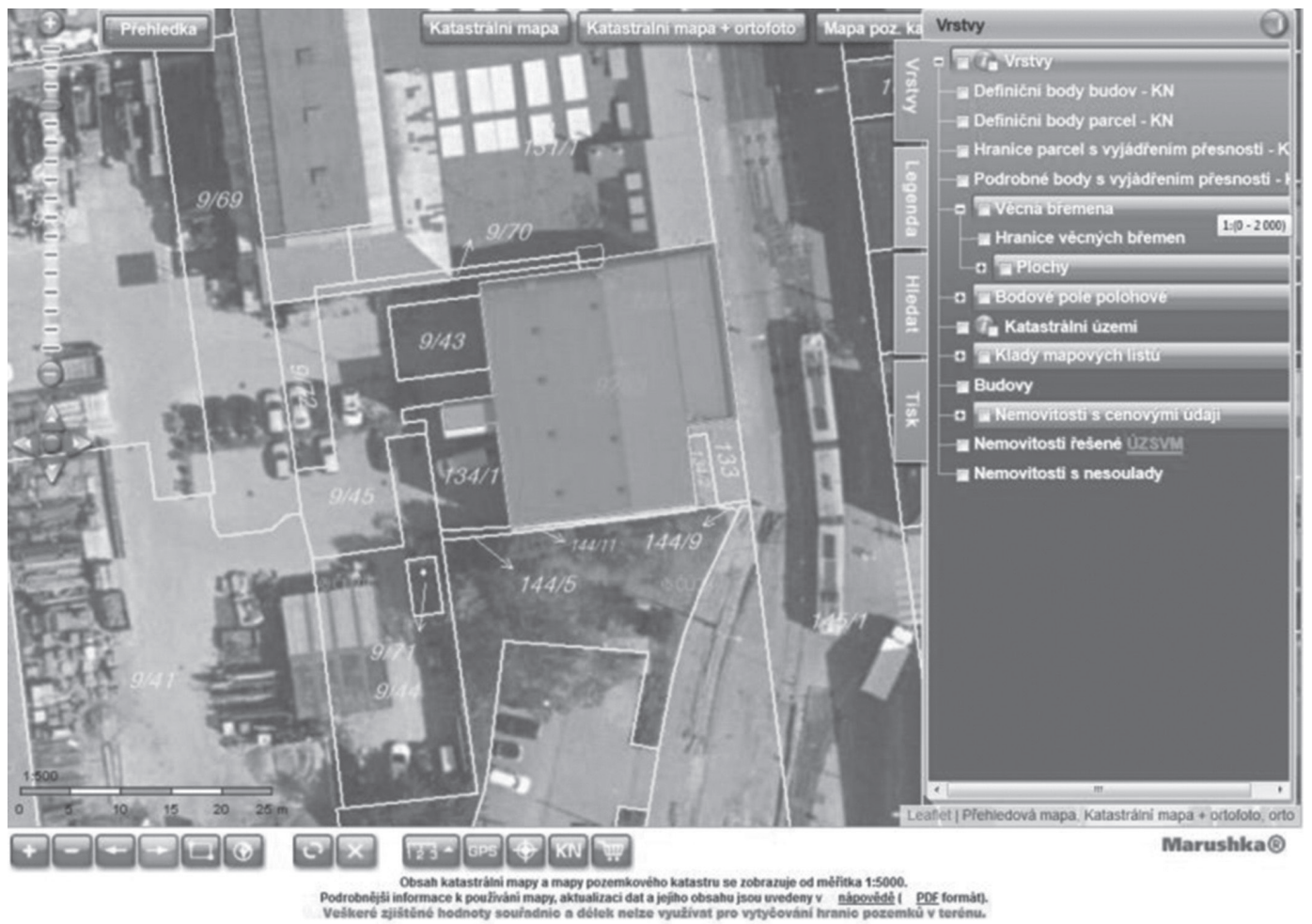

Obr. 1 Výřez soutisku katastrální mapy a orotofoto - bez vyznačení omezení (zdroj: http://sgi.nahlizenidokn.cuzk.cz/marushka/....).

Fig. 1 Cutout of interleaved cadastral map and ortophoto - without limitations (source: http://sgi.nahlizenidokn.cuzk.cz/marushka/....). 


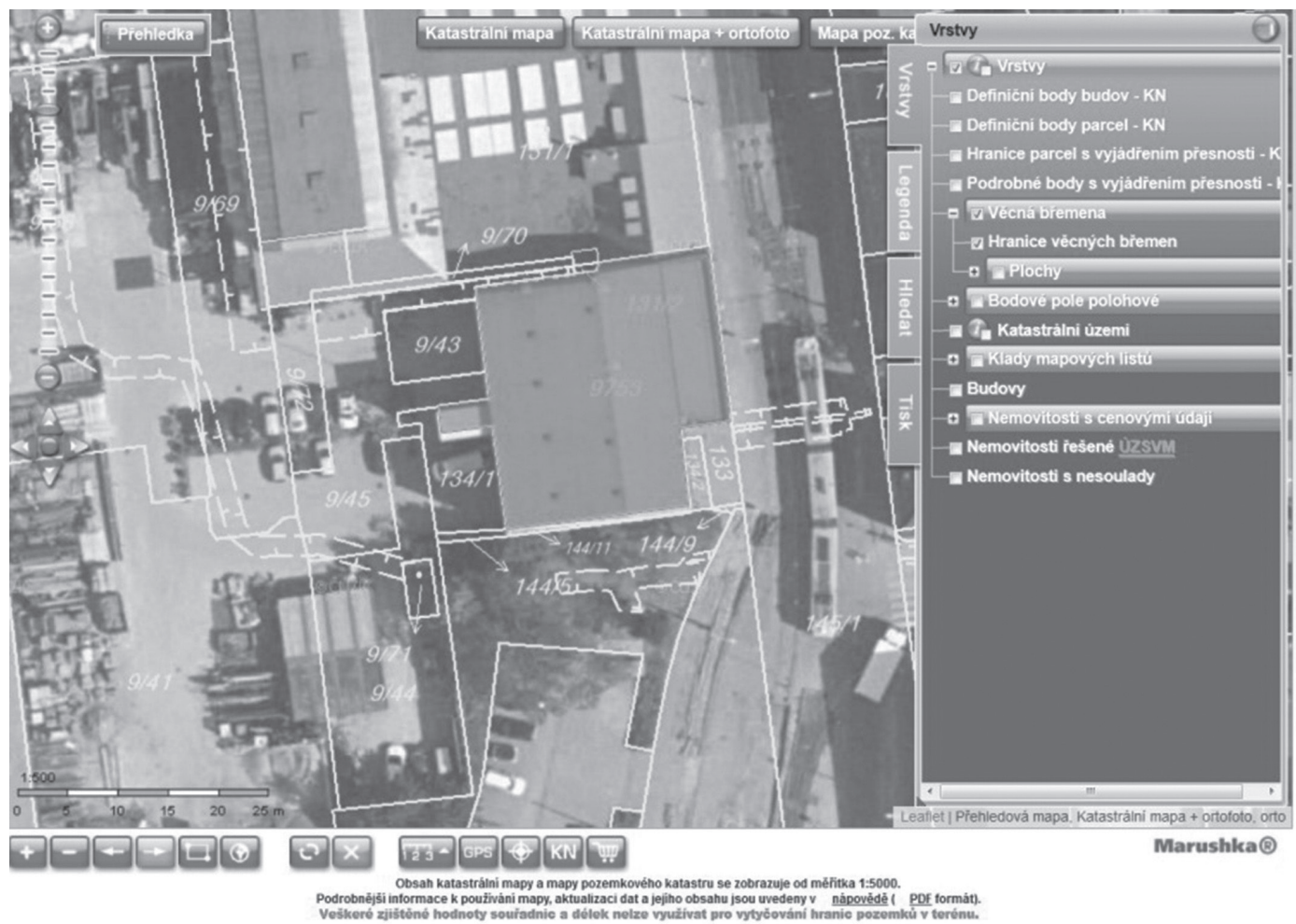

Obr. 2 Výřez soutisku katastrálni mapy a ortofoto - s vyznačením omezení na části pozemku (zdroj: http://sgi.nahlizenidokn.cuzk.cz/marushka/....).

Fig. 2 Cutout of interleaved cadastral map and ortophoto-indicating limitations on part of the land (source: http://sgi.nahlizenidokn.cuzk.cz/marushka/....).

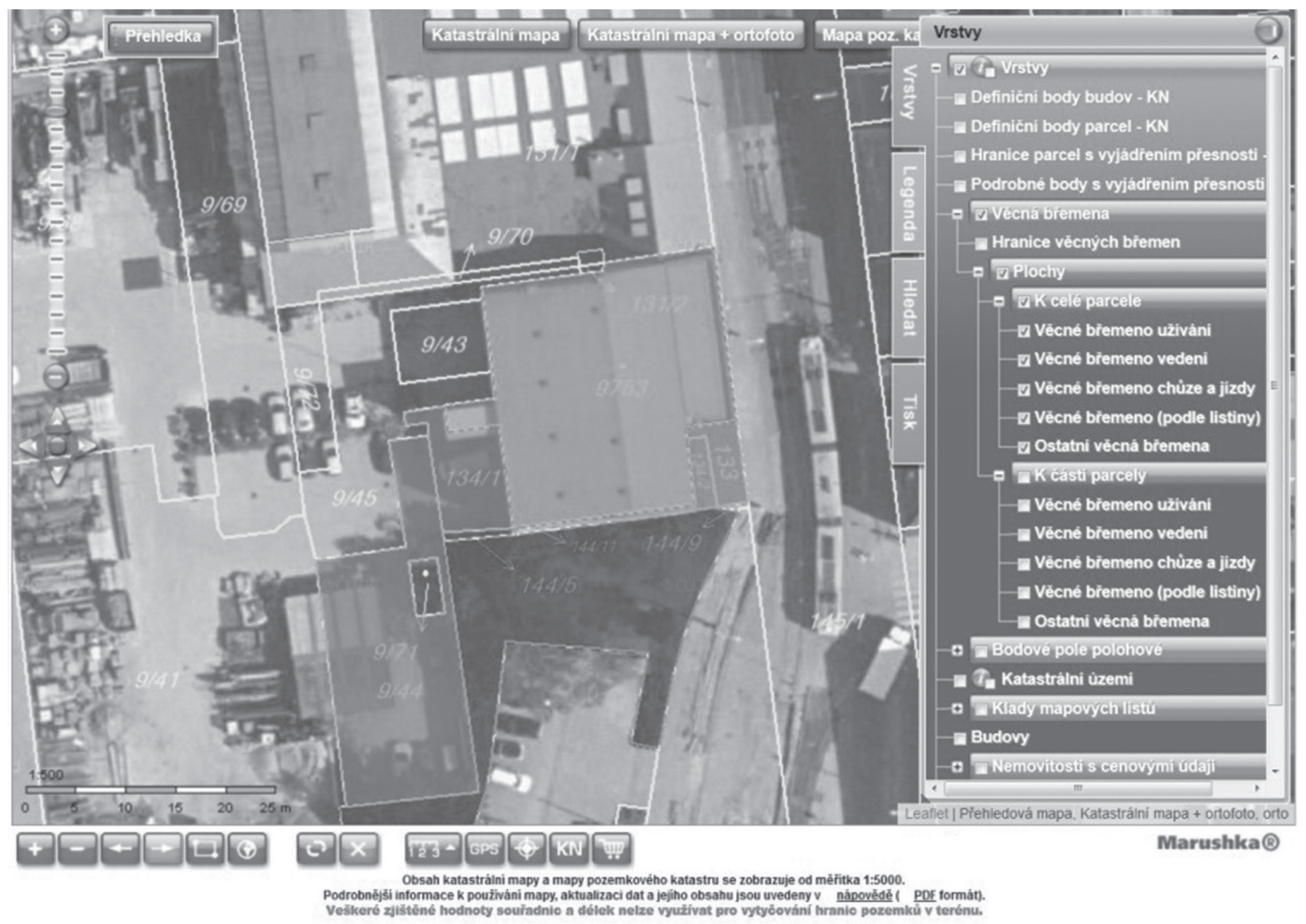

Obr. 3 Výřez soutisku katastrální mapy a ortofoto - vyznačení zatižení věcného břemene k celé parcele (zdroj: http://sgi.nahlizenidokn.cuzk.cz/marushka/....).

Fig. 3 Cutout of interleaved cadastral map and ortophoto - indicating limitations of the load to the whole land (source: http://sgi.nahlizenidokn.cuzk.cz/marushka/....). 


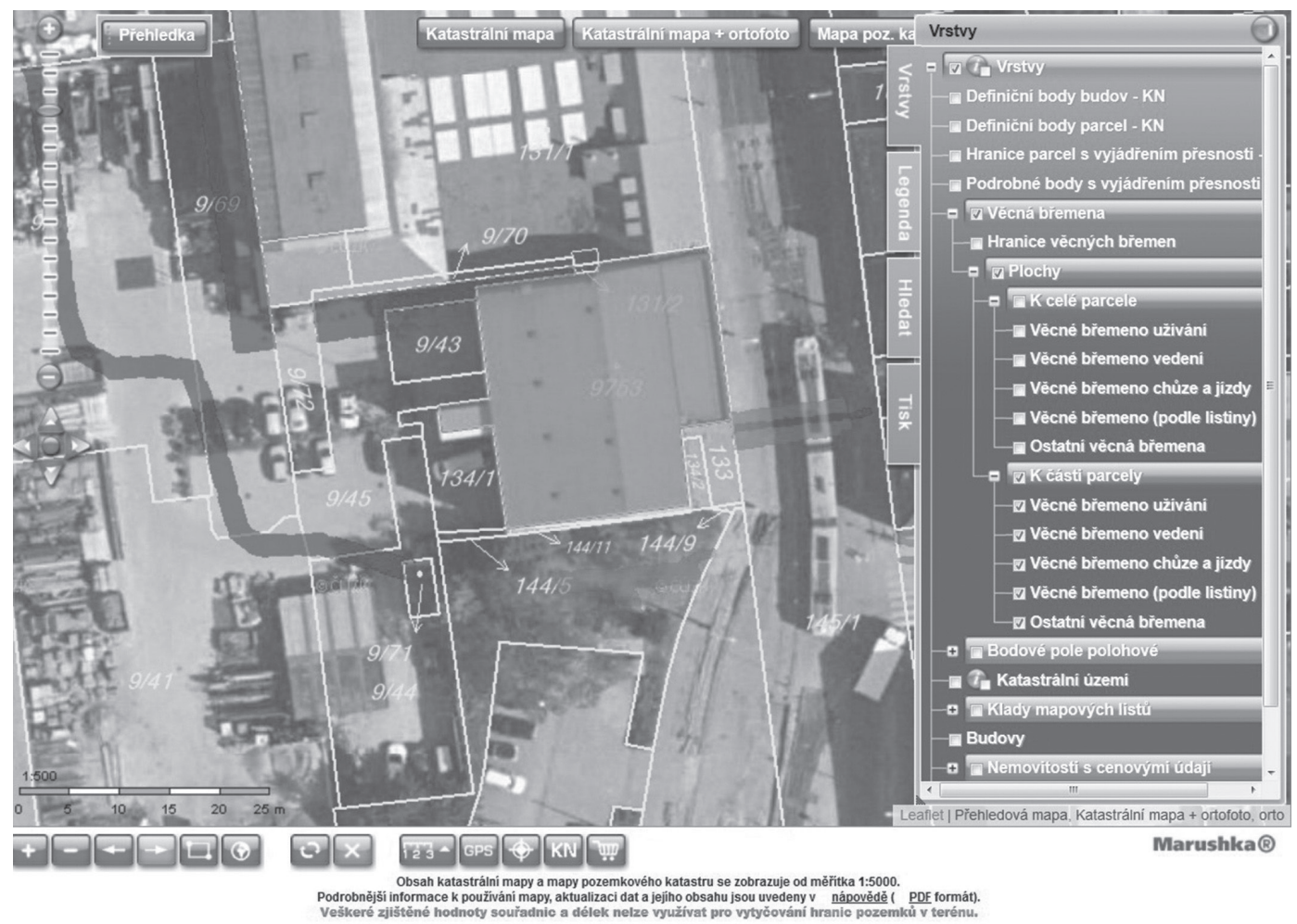

Obr. 4 Výřez soutisku katastrální mapy a ortofoto - vyznačení zatiženi věcného břemene k části parcely (zdroj: http://sgi.nahlizenidokn.cuzk.cz/marushka/....).

Fig. 4 Cutout of interleaved cadastral map and ortophoto - indicating limitations on part of the land (source: http://sgi.nahlizenidokn.cuzk.cz/marushka/....).

Další nabízená služba je možnost volby druhu věcného břemene (věcné břemeno užívání, věcné břemeno vedení, věcné břemeno chůze a jízdy, věcné břemeno (podle listiny), ostatní věcná břemena). Na mapě se vybraný druh zobrazuje formou barev, které jsou popsány v legendě. Nevýhodou jsou zvolené barvy, které často splývají, a nelze přesně identifikovat, o kterou barvu se jedná, tedy o jaký druh věcného břemene.

\subsubsection{Nemovitosti s cenovými údaji}

Skutečnost, že katastr nemovitostí je veřejným seznamem, tudíž nahlížení do katastru je umožněno opravdu každému občanovi (fyzické i právnické osobě). Př́i nahlížení do katastru nemovitostí jsou však volně dostupné informace omezeny. Mezi omezené informace patř́ i cenový údaj.

Co pojem cenový údaj znamená? „Cenový údaj je údaj o dosažené kupní ceně nemovitosti nebo skupiny nemovitosti. ", takto je tento pojem definován v katastrální vyhlášce č. 357/2013 Sb. v § 24 odst. 1 [8]. Cenový údaj je na katastru evidován k dané listině, sloužící jako podklad pro vklad. Informaci o cenovém údaji je možno získat dvěma způsoby. Jeden způsob získání cenového údaje je ze sbírky listin - kopie smlouvy (listinná forma). Druhý způsob získání cenových údajů je elektronickou cestou. Vklady do katastru nemovitostí provedené po 1 . lednu 2014 jsou již provedeny v elektronické podobě a získání údajů je tudíž možné právě elektronickou cestou. Státní správa katastru nemovitostí nabízí uživatelům získání přehledu cenových údajů dvojí cestou.

První způsob je možný výpisem cenových údajů zanesených do katastru nemovitostí, a to bud' celé ČR nebo vybraného území, za jednotlivé roky (2014, 2015, 2016 a 2017) formou excelové tabulky.

Druhý způsob je vyhledáním v mapovém portálu. Pro práci uživatelů (znalců/odhadců) je vhodné využívat služeb vyhledávání cenových údajů pomocí mapy. Při oceňování nemovitostí, kdy znalec/odhadce má za úkol ocenit danou nemovitost, se autorkám jeví lepším způsob vyhledávání cenových údajů přes mapový portál. V mapě si uživatel může vybrat, ze kterého roku cenový údaj potřebuje (2014-2017), může vybírat nemovitosti pro srovnání a omezit rozsah okolí pro správný výběr.

$\mathrm{Na}$ obr. 6 je uveden př́klad zobrazení v mapovém portálu. Zelenou barvou jsou podbarveny nemovitosti, u nichž je veden cenový údaj, červenou vyšrafovanou barvou jsou zobrazeny nemovitosti, u nichž je cenový údaj vázán na jednotku a podíly na společných částech domu.

\begin{tabular}{|c|c|c|c|c|c|c|c|c|c|c|}
\hline$\Delta$ & A & B & C & D & E & $\mathrm{F}$ & G & H & I & J \\
\hline 1 & Čislo řizení & Datum podání & Datum zplatnění & Listina & Typ nemovitosti & Nemovitost & k.ú. & RIZENI_ID & LISTINA_ID & ID_NEMOVITOSTI \\
\hline 2 & $V-1 / 2014-303$ & 2.1.2014 8:12 & 19.2.2014 6:15 & Smlouva kupní & PAR & č. 126/3 Střibřec & Střibřec 757853 & 28886347010 & 20959791010 & 28359159010 \\
\hline 3 & $V-1 / 2014-303$ & 2.1.2014 8:12 & 19.2.2014 6:15 & Smlouva kupní & PAR & č. $126 / 4$ Střibřec & Střibřec 757853 & 28886347010 & 20959791010 & 28359160010 \\
\hline 4 & $V-1 / 2014-303$ & 2.1.2014 8:12 & $19.2 .20146: 15$ & Smlouva kupní & PAR & č. $126 / 5$ Stříbřec & Střibřec 757853 & 28886347010 & 20959791010 & 28359161010 \\
\hline
\end{tabular}

Obr. 5 Ukázka výpisu k cenovým údajům excelovou tabulkou (zdroj: http://nahlizenidokn.cuzk.cz/nas/cenoveudaje/cr/).

Fig. 5 A sample of the statement of price data is an excellent table (source: http://nahlizenidokn.cuzk.cz/nas/cenoveudaje/cr/). 


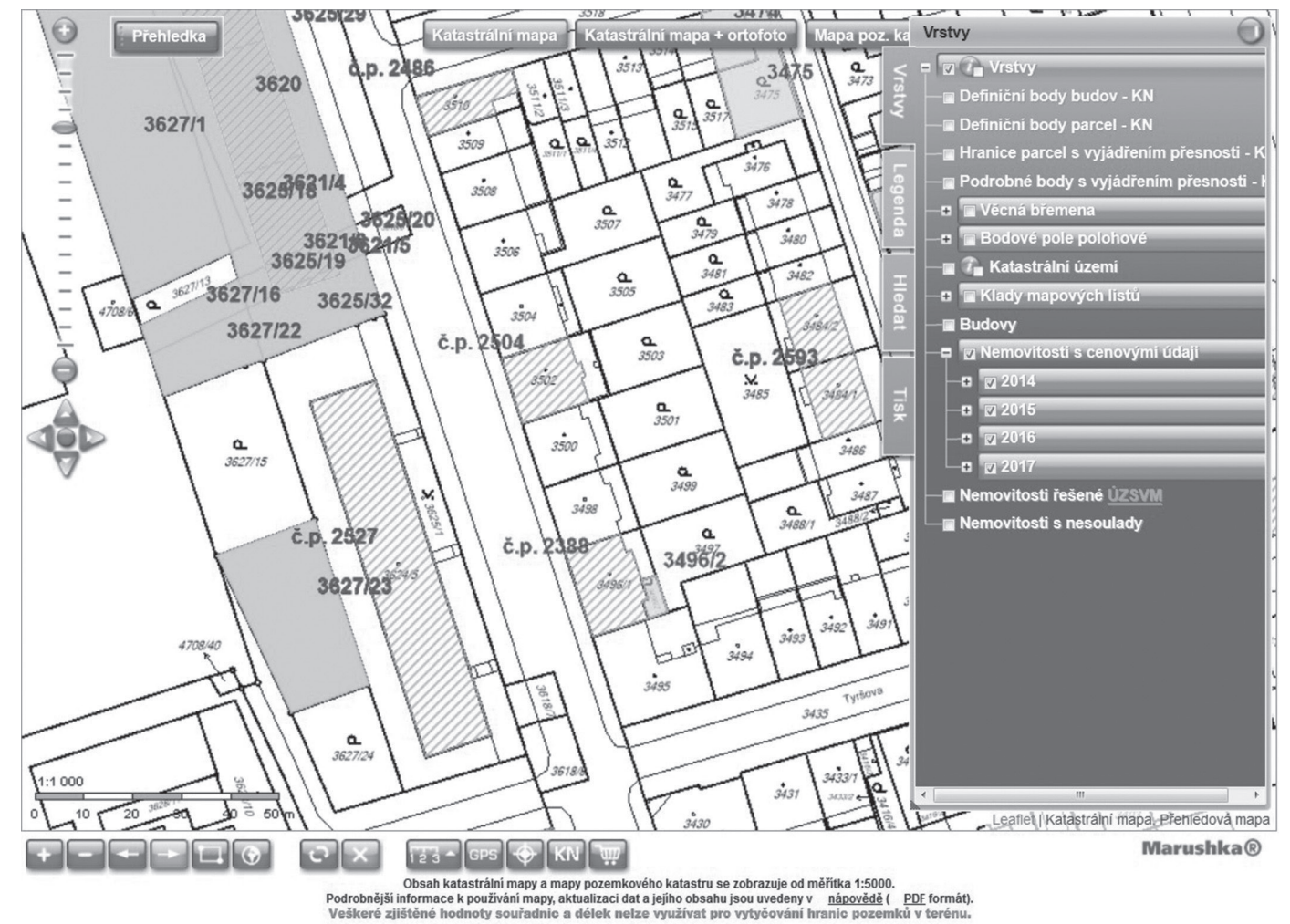

Obr. 6 Výřez katastrální mapy - vyznačení nemovitostí s evidovanými cenovými údaji (zdroj: http://sgi.nahlizenidokn.cuzk.cz/marushka/....). Fig. 6 Cutout of cadastral map-identification of real estates with registered price data (source: http://sgi.nahlizenidokn.cuzk.cz/marushka/....).

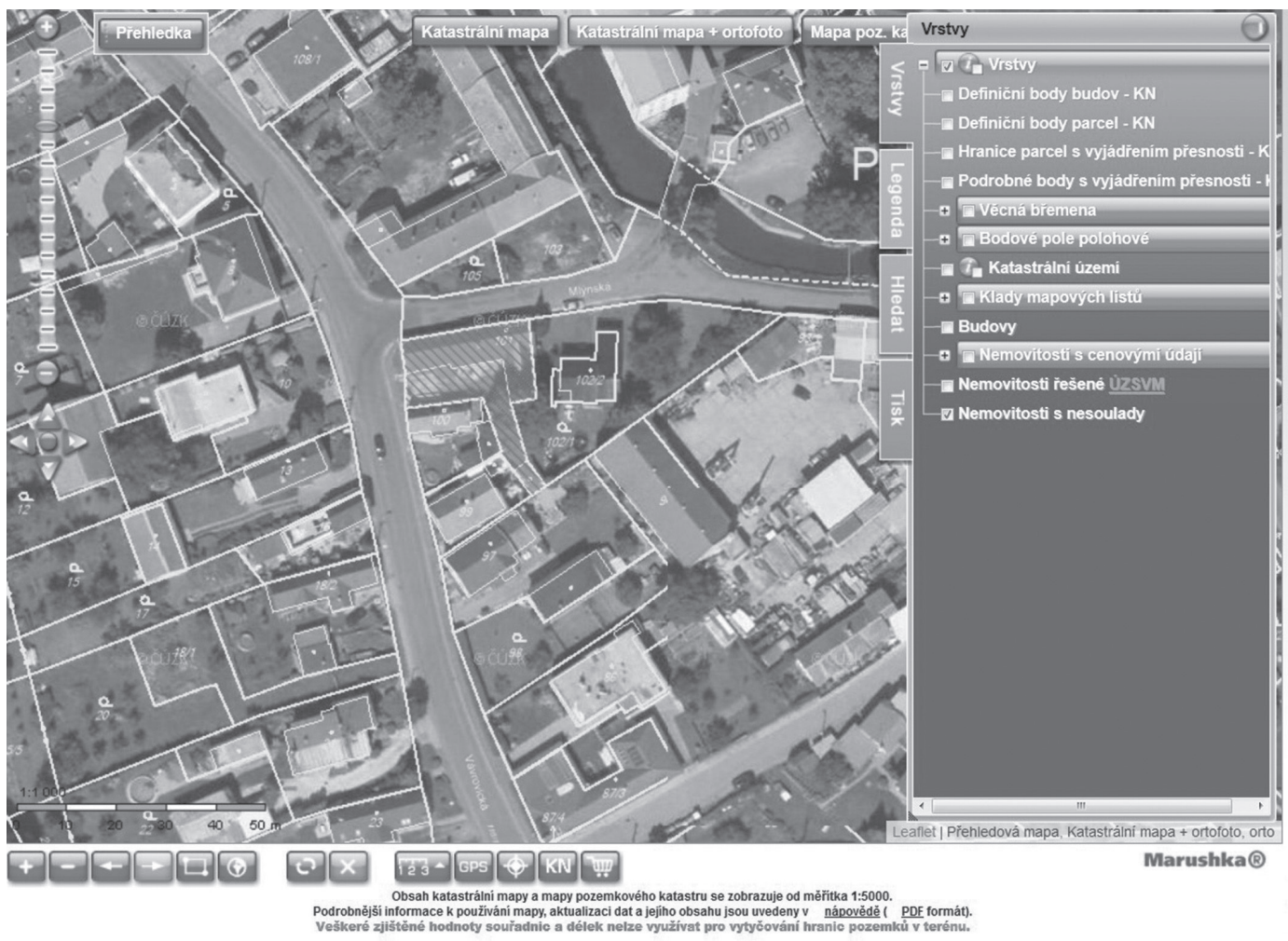

Obr. 7 Výřez soutisku katastrální mapy a ortofoto - vyznačení nemovitosti řešené ÚZSVM (zdroj: http://sgi.nahlizenidokn.cuzk.cz/marushka/....).

Fig. 7 Cutout of interleaved cadastral map and ortophoto - designation of real estate addressed by UZSVM (source: http://sgi.nahlizenidokn.cuzk.cz/marushka/....). 


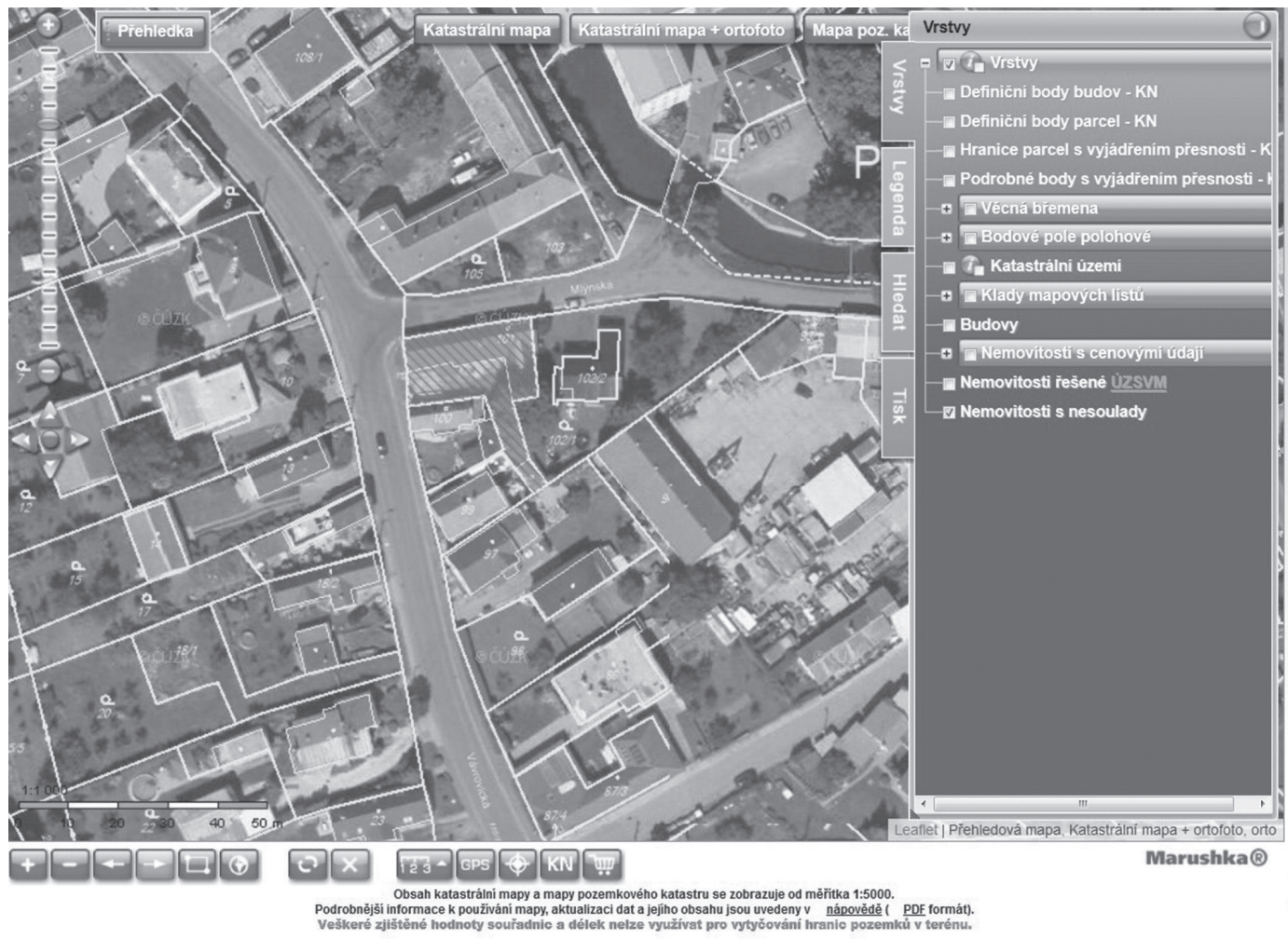

Obr. 8 Výřez soutisku katastrální mapy a ortofoto - vyznačení nemovitosti s nesoulady (zdroj: http://sgi.nahlizenidokn.cuzk.cz/marushka/....). Fig. 8 Cutout of interleaved cadastral map and ortophoto - identification of real estate with cadastral inconsistencies (source: http://sgi.nahlizenidokn.cuzk.cz/marushka/....).

\subsubsection{Nemovitosti řešené ÚZSVM (Úřad pro zastupování státu ve věcech majetkových)}

„Nemovitosti řešené ÚZSVM“ tento pojem specifikuje nemovitosti, u nichž není dostatečně uveden vlastník - zcela chybí identifikace vlastníka nebo je vlastník uveden, ale bez dostatečné identifikace [9].

V katastrálním zákoně č. 256/2013 Sb., v platném znění [1] je v § 64 uvedena povinnost Českého úřadu zeměměřického a katastrálního předat údaje o nemovitosti, u nichž není osoba jako vlastník označena dostatečně určitě, Úřadu pro zastupování státu ve věcech majetkových, který vede její evidenci a další zákonem stanovené kroky.

Účelově vyhledávat nemovitosti, které jsou předány do evidence ÚZSVM, nabízí služba v mapovém portálu. Opět pomocí „vrstvy“ je možno zapnout „nemovitosti řešené ÚZSVM“. V př́padě, že v hledané lokalitě se nacházejí nemovitosti takto řešené, se v mapě modře vyšrafuje předmětná nemovitost.

$\mathrm{Na}$,informativním výpisu“ je tento stav zanesen v kolonce “jiné zápisy", kde je uvedeno: "Nedostatečně identifikovaný vlastník údaje o nemovitosti predány do evidence ÚZSVM. Vice na http:// www.uzsvm.cz".

\subsubsection{Nemovitosti s nesoulady}

Jedním z mnoha úkolů, které katastrální úřady musí provádět, je i tzv. revize údajů katastru, jak je uvedeno v zákoně č. 256/2013 Sb. [1]. $\mathrm{V} \S 35$ odst. 1 je uvedeno „Katastrálni úr̆ad reviduje soulad údajů katastru se skutečným stavem v terénu. Revizi údajů katastru (dále jen „revize katastru“) vyhlašuje příslušný katastrální úr̆ad podle potřeby zajištěni souladu údaju katastru s jejich skutečným stavem v terénu a provádí ji za součinnosti obci, poprípadě též orgánů veřejné moci, a za účasti vlastnikư a jiných oprávněných. Zjistí-li nesoulad v údajích katastru, projedná způsob jeho odstraněni. “

Jedná se zejména o zpřesňování (geometrické i polohové) nemovitostí v terénu, at' už se jedná o obvody budov, hranic pozemků, způsobu využití pozemku atd. [10]. Tyto stavy vznikají nejčastěji neoprávněnými lidskými zásahy na nemovitostech. Pokud chce uživatel v aplikaci nahlížení do katastru nemovitostí zjistit, zda předmětná nemovitost má nesoulad, může k tomu opět použít mapový portál, kdy u nemovitosti s nesouladem zaevidovaným na katastru se skutečným stavem se předmětná nemovitost vyšrafuje.

V „informativním výpisu“ se nově zobrazí kolonka „,nesoulady“, která je umístěna pod údaji o vlastnictví, s popisem dle obr. 9:

\begin{tabular}{|l|l|}
\hline Popis & Řizeni \\
\hline Nesoulad zobrazení obvodu budovy se skutečným stavem & $\underline{\text { ZDŘ-133/2017 }}$ \\
\hline
\end{tabular}

Obr. 9 Ukázka z informativního výpisu při nahližení do katastru (zdroj: http://nahlizenidokn.cuzk.cz /....).

Fig. 9 Sample of informative statement from cadastral (source: http://nahlizenidokn.cuzk.cz /....). 


\section{ZÁVĚR}

Pro znaleckou činnost jsou webové stránky ČÚZK nepostradatelným zdrojem informací. Webové stránky jsou v průběhu času zdokonalovány; uživatelům nabízejí širokou škálu informací, dostupnou z jakéhokoliv místa nejen v České republice. Je důležité, aby občané a zejména odborná znalecká veřejnost byla informována o možnostech, které zrychlují a zjednodušují přístup k informacím.

\section{LITERATURA}

[1] Zákon č. 256/2013 Sb., o katastru nemovitostí (katastrální zákon), ve znění pozdějších předpisů. In: ASPI [právní informační systém]. Wolters Kluwer ČR.

[2] Zákon č. 89/2012 Sb., občanský zákoník. In: ASPI [právní informační systém]. Wolters Kluwer ČR.

[3] BAREŠOVÁ, E., BLÁHOVÁ, I., DOUBEK, P., JANEČEK, B., NEDVÍDEK, L., ŠANDOVÁ, H. aj. Katastrální zákon. Komentář. Vydání Praha: Wolters Kluwer, ISBN 978-80-7478-703-4.

[4] Zákon č. 344/1992 Sb., o katastru nemovitostí České republiky (katastrální zákon), ve znění pozdějších předpisů. In: ASPI [právní informační systém]. Wolters Kluwer ČR.
[5] Zákon č. 265/1992 Sb., o zápisech vlastnických a jiných věcných práv k nemovitostem, ve znění pozdějších předpisů. In: ASPI [právní informační systém]. Wolters Kluwer ČR.

[6] Český úřad zeměměřický a katastrální [online] 2018. Dostupné z: http://www.cuzk.cz/

[7] Vyhláška č. 358/2013 Sb., o poskytování údajů z katastru nemovitostí, ve znění pozdějších předpisů. In: ASPI [právní informační systém]. Wolters Kluwer ČR.

[8] Vyhláška č. 357/2013 Sb., o katastru nemovitostí (katastrální vyhláška), ve znění pozdějších předpisů. In: ASPI [právní informační systém]. Wolters Kluwer ČR.

[9] Úřad pro zastupování státu ve věcech majetkových, www. uzsvm. $c z$ [online] 2011, <https://www.uzsvm.cz/nedostatecne-urciteidentifikovani-vlastnici-2140-0-85>

[10] Český úřad zeměměřický a katastrální [online] 2018, cit. [cit. 18. 1. 2018] Dostupné z: $<$ http://www.cuzk.cz/Urady/Katastralniurady/Katastralni-urady/Katastralni-urad-pro-Karlovarsky-kraj/ Casto-hledane-informace/Revize-katastru-nemovitosti/Revize letak.aspx>

[11] KOMOSNÁ, M., GARDÁŠOVÁ, A. Využití českého úřadu zeměměřického a katastrálního jako zdroje informací. In: $E x F o S$ 2018: sbornik z XXVII. mezinárodní vědecké konference soudního inženýrství, konané ve dnech 1. - 2. února 2018 v Brně. Brno: VUT v Brně, Ústav soudního inženýrství, 2018, s. 374-383. ISBN: 978-80-214-5600-6.

\section{Správná citace:}

KOMOSNÁ, M., GARDÁŠOVÁ, A., ŠKOPKOVÁ, L. Využití českého úřadu zeměměřického a katastrálního jako zdroje informací. Soudní inženýrství, 2018, 29(3), 26-32. ISSN 1211-443X. 